\title{
The Relevance of Lactate Levels in Acute Seizure
}

Jessica Sop DO ${ }^{1}$, Jessica Rogers DO ${ }^{1}$, Nnennaya Opara MD MPH ${ }^{1,2}$, Alfred Tager

$\mathrm{MD} \mathrm{MPH}^{3}$, Scott Dean $\mathrm{PhD}^{2}$, Mark L Gustafson $\mathrm{DO}^{1}$

1. Emergency Medicine, Charleston Area Medical Center, Charleston, USA.

2. CAMC Education and Research Institute, Charleston Area Medical Center, Charleston, USA.

3. Internal Medicine, Charleston Area Medical Center, Charleston, USA

\section{Introduction}

Seizures can result in profound elevations of serum lactate. A paucity of investigation into whether lactate levels in these patients is associated with increased mortality. We sought to evaluate the significance in patients presenting with a seizure and elevated lactate.

\section{Methods}

This is a retrospective study involving patients presenting to the Emergency Department (ED) with a diagnosis of seizure from September 1st, 2016 until March 31st, 2018. Those with normal serum lactate (< $2 \mathrm{mmol} / \mathrm{L}$ ) were compared with patients that had an elevated serum lactate $(\geq 2 \mathrm{mmol} / \mathrm{L})$.

\section{Results}

Patients with normal serum lactate levels had a significantly longer length of stay in the ED (60 minutes $\mathrm{p}=0.04$ ) when compared to those with elevated serum lactate levels. Additionally, a higher percentage of patients with elevated serum lactate received intravenous fluids in the ED (54.69\% vs. $35.4 \%, \mathrm{P}=0.01$ ). There was no significant difference in other measured variables. 


\section{Conclusion}

This study illustrates that serum lactate levels do not directly correlate with indicators of disease severity or outcomes when elevated secondary to seizure. However, patients with normal serum lactate levels had a longer length of stay in the ED.

Keywords: Lactate, Lactic Acid, Seizure, Epilepsy, Length of Stay

\section{Introduction}

A seizure is a sudden surge of electrical activity in the brain ${ }^{1}$. The electrical activity that occurs in the human brain during seizures are caused by complex chemical alteration in the nerve cells. Seizures in of themselves are not a disease, rather, they are a symptom of a disorder that is affecting the brain. While some seizures occur unnoticed, others are totally disabling. Acute seizure accounts for about 1 million ER visits annually, which is approximately $1 \%$ of total ER visits ${ }^{2}$. A systematic review of US healthcare costs for patients with seizure disorder revealed that epilepsy-specific costs ranged from $\$ 1,022$ to $\$ 19,749$ per person annually ${ }^{3}$.

Serum lactate has been used as a predictor for risk of morbidity and mortality in many disease states. It has been widely used as an indicator of disease severity and mortality in sepsis and trauma ${ }^{4,5}$. Lactate has also been known to dramatically increase in the presence of acute seizure ${ }^{6}$. Pre-existing medical conditions, seizure type, duration and intensity influence the resultant physiologic effects' muscle contractions, increased oxygen demand and impaired breathing instigate temporary tissue hypoxia and hypoperfusion during a tonic-clonic seizure ${ }^{7}$.

Lactate is generated during this transient state of hypoxia as a product of anaerobic metabolism of glucose ${ }^{8}$. Studies as early as 1977 have illustrated that lactic acidosis 
associated with seizure is self-limited and resolves even without intervention with a half-life of approximately $50 \%$ at 1 hour. Hence, when there is no other underlying cause for lactic acidosis, seizures can be considered a self-resolving lactic acidosis state ${ }^{9,10}$. It is a consequence of cessation of source production when the seizure stops ${ }^{11}$. Clinical symptoms such as bite on tongue, drowsiness, incontinence all may hint at epileptic seizure and can also occur in non-epileptic seizures. This makes some diagnostic examinations such as computer tomography of head (Head CT), or Electro encephalography (EEG) unreliable in the diagnosis of seizures. Thus, making the laboratory markers such as creatinine kinase, lactic acid and prolactin very useful as they are all increased after an epileptic tonic-clonic seizure episode ${ }^{12}$. Additionally, blood $\mathrm{pH}$ generally normalizes within 1 hour, and so, despite significant lactic acidosis, severe metabolic acidemia is not expected following the postictal recovery period subsequent to a generalized tonic-clonic seizures ${ }^{13,14}$. Therefore, persistent lactic acidosis beyond 1-2 hours following a seizure warrants further investigation $9,10,15$.

\section{Materials and Methods}

An observational, retrospective study was approved, and ethical approval (IRB: 18-444) was issued by the Charleston Area Medical Centre Institutional Review Board. Data were collected from patients who presented to the emergency department with the primary diagnosis of seizure. The data collection period was from September 12, 2017 through March 31, 2018.

Inclusion criteria for this study were patients who had the primary diagnosis of seizure and were $\geq 18$ years of age. Patients were excluded if they were under 18 years of age or sustained trauma. Additionally, pregnant patients, end-stage renal disease patients, and patients taking metformin were eliminated. Furthermore, patients with an elevated 
ethanol level were excluded because of its ability to skew relative outcomes with regard to lactate elevation ${ }^{16}$.

A serum lactate level of $<2 \mathrm{mmol} / \mathrm{L}$ was set as normal and anything above it was considered an elevated lab value ${ }^{17}$. The measured variables, including sex, median age, antibiotic use, urine drug screen performed, Use of anti-epileptic medication, fluid administration, number of comorbidities and rate of admission, were compared between the two study groups as exhibited in table-1and table- 2 .

Table-1: Descriptive Information regarding study groups

\begin{tabular}{|l|l|l|}
\hline Variables & $\begin{array}{l}\mathrm{LA}<2 \mathrm{mmol} / \mathrm{L} \\
(\mathrm{N}=115)\end{array}$ & $\begin{array}{l}\mathrm{LA}>2 \mathrm{mmol} / \mathrm{L} \\
(\mathrm{N}=64)\end{array}$ \\
\hline Gender (male \& female) & $50(43.5 \%)$ & $29(45.3 \%)$ \\
\hline Age - Median (Range) & $40(18-80)$ & $38(18-82)$ \\
\hline Antibiotic Use & $4(3.9 \%)$ & $2(3.2 \%)$ \\
\hline Urine Drug Screen & $20(19.8 \%)$ & $15(25.9 \%)$ \\
\hline Anti- Seizure Meds Use & $80(72.1 \%)$ & $36(58.1 \%)$ \\
\hline $\begin{array}{l}\text { Total amount of Fluids } \\
\text { Given }\end{array}$ & $40 \mathrm{~L}(35.4 \%)$ & $35 \mathrm{~L}(54.7 \%)$ \\
\hline \# of Comorbidities & & \\
\hline 0 & $30(26.1 \%)$ & $27(42.2 \%)$ \\
\hline 1 & $49(42.6 \%)$ & $15(23.4 \%)$ \\
\hline 2 & $22(19.1 \%)$ & $14(21.9 \%)$ \\
\hline 3 & $10(8.7 \%$ & $3(4.7 \%)$ \\
\hline 4 & $2(1.7 \%)$ & $4(6.3 \%)$ \\
\hline 5 & $2(1.7 \%)$ & $1(1.6 \%)$ \\
\hline Admission rate & $9(7.8 \%)$ & $3(4.7 \%)$ \\
\hline
\end{tabular}

LA: lactic acid

When IV fluids were administered, isotonic fluid was used. As noted, some patients received antibiotics in the ED if they were suspected to have an underlying infection causing their seizure. A urine drug screen was performed on patients who were thought to have used an illicit substance based on history and physical exam. Because we found that the majority of patients had a history of at least one medical condition, number of 
comorbidities was a parameter that we evaluated. Admission rate was analysed noting that admitted patients were primarily observed overnight.

\section{Statistical analysis}

Data analysis was performed using SAS 9.3 basic descriptive statistics, such as means and standard deviations for continuous variables, and proportions and frequencies for categorical variables, were used to analyse patient characteristics. Continuous variables were grouped and converted to categorical variables for data analysis. Comparisons were made using two-sample t-test for continuous values, and Chi-square test/Fisher's Exact Test for categorical variables. A p level of $<0.05$ was used to determine statistical significance.

\section{Results}

A total of 181 patients were identified within the specified time frame after application of the exclusion criteria. Of these, two additional patients were excluded since no data were recorded on their lactate levels. Patients were allocated into either the normal serum lactate group or elevated serum lactate group. Serum lactate levels are known to be affected by several of these. Seizure disorder was noted to be the foremost comorbid diagnosis in both groups. Alcoholism listed as a comorbidity is in reference to patients who have an alcoholic disorder but were not intoxicated at the time of evaluation.

When the two groups were compared across all comorbidities, no statistical significance was noted.

The only variables statistically significant between the two groups were fluid use and Emergency Department length of stay (ED LOS) as illustrated in table-3 As would be expected, significantly more patients with elevated serum lactate received intravenous (IV) fluids than those in the normal serum lactate group (54.69\% vs. $35.4 \%, \mathrm{p}=0.01)$. 
Interestingly, the median LOS was 60 minutes less in the elevated serum lactate group than in the normal lactate group (255 min vs. $195 \mathrm{~min})$. The median calculation was used rather than the mean to avoid skewing the data secondary to extreme outliers. Antiepileptic medication use was higher in the normal serum lactate group but did not reach statistical significance $(72.1 \%$ vs $58.1 \%, \mathrm{p}=0.06)$. No difference was found in the number of patients who had a drug screen performed; similarly, the number of patients with positive urine drug tests were not significantly different between those with normal serum lactate and those with elevated serum lactate (50\% vs. $64.29 \%, \mathrm{p}=0.4)$. Of note, two patients in the normal serum lactate group didn't have a urine drug screen, hence the nine that were reported as positive in this group equated to a $50 \%$ positive rate. Positive results were reported for tetrahydrocannabinol (THC), amphetamines, opioids, benzodiazepines, ecstasy and cocaine. Renal function (BUN and creatinine $(\mathrm{Cr})$ ), shock index (heart rate/systolic blood pressure), rate of admission and rate of re-admission at 72 hours were all found to be similar between the two groups.

Table-2: percentage of other Comorbidities in the Group.

\begin{tabular}{|l|l|l|l|}
\hline Comorbidities & $\begin{array}{l}\text { LA }<2 \mathrm{mmol} / \mathrm{L} \\
(\mathrm{N}=11.5)\end{array}$ & $\begin{array}{l}\text { LA } 2 \mathrm{mmol} / \mathrm{L} \\
(\mathrm{N}=64)\end{array}$ & P-Value \\
\hline Hypertension & $19.1 \%$ & $12.5 \%$ & 0.255 \\
\hline Diabetes Mellitus & $4.4 \%$ & $7.8 \%$ & 0.333 \\
\hline $\begin{array}{l}\text { Congestive Heart } \\
\text { failure }\end{array}$ & $0.9 \%$ & $0 \%$ & 1 \\
\hline $\begin{array}{l}\text { Chronic Obstructive } \\
\text { Pulmonary Disease. }\end{array}$ & $2.6 \%$ & $4.7 \%$ & 0.668 \\
\hline Active Malignancy & $6.1 \%$ & $6.3 \%$ & 1 \\
\hline $\begin{array}{l}\text { Coronary Artery } \\
\text { Disease }\end{array}$ & $1.7 \%$ & $4.7 \%$ & 0.3505 \\
\hline $\begin{array}{l}\text { Deep Venous } \\
\text { Thrombosis }\end{array}$ & $1.7 \%$ & $4.7 \%$ & 0.3505 \\
\hline Obesity & $15.7 \%$ & $9.4 \%$ & 0.2375 \\
\hline Seizure Disorder & $58.3 \%$ & $48.4 \%$ & 0.2057 \\
\hline Drug Addiction & $3.5 \%$ & $6.3 \%$ & 0.459 \\
\hline Alcoholic & $7.8 \%$ & $6.3 \%$ & 0.7735 \\
\hline
\end{tabular}




\begin{tabular}{|l|l|l|l|}
\hline Other & $0.9 \%$ & $3.1 \%$ & 0.291 \\
\hline
\end{tabular}

LA: lactic acid

: Table-3Statistical Significance between Variables.

\begin{tabular}{|l|l|l|l|}
\hline Variables & LA<2 mmol/L & LA $>2 \mathrm{mmol} / \mathrm{L}$ & P-value \\
\hline Shock Index (Range) & $1.5(0.9-3)$ & $1.4(0.9-2.6)$ & 0.0908 \\
\hline $\begin{array}{l}\text { Rate of Admission } \\
(\%)\end{array}$ & $9(7.8 \%)$ & $3(4.7 \%)$ & 0.5419 \\
\hline $\begin{array}{l}\text { Rate of Readmission } \\
\text { (72hr) }\end{array}$ & $8(7.0 \%)$ & $7(10.9 \%)$ & 0.3569 \\
\hline ED LOS (minutes). & $255(96-1169)$ & $195(72-1335)$ & $0.0422^{*}$ \\
\hline BUN & $12(3-48)$ & $11.5(5-40)$ & 0.7982 \\
\hline Cr & $0.8(0.4-3.9)$ & $0.9(0.4-1.8)$ & 0.5483 \\
\hline Fluids (Liters) & $1(0.1-2.3)$ & $1(0.1-2.0)$ & 0.6838 \\
\hline Rate of Fluids (Use) & $40(35.4 \%)$ & $35(54.69)$ & $0.0126^{*}$ \\
\hline Gender (M\&F) & $50(43.5 \%)$ & $29(45.3 \%)$ & 0.8128 \\
\hline Age (Range) & $40(18-80)$ & $38(18-82)$ & 0.5941 \\
\hline $\begin{array}{l}\text { Antibiotic } \\
\text { Administration rate }\end{array}$ & $4(3.9 \%)$ & $2(3.2 \%)$ & 1 \\
\hline \# of Comorbidities & $1(0-5)$ & $1(0-5)$ & 0.3174 \\
\hline $\begin{array}{l}\text { Urine Drug Screen } \\
\text { rate }\end{array}$ & $20(19.8 \%)$ & $15(25.9 \%)$ & 0.3747 \\
\hline $\begin{array}{l}\text { Urine Drug Screen- } \\
\text { positive rate }\end{array}$ & $9(50 \%)$ & $9(64.29 \%)$ & 0.419 \\
\hline $\begin{array}{l}\text { Anti-epileptic meds } \\
\text { use rate }\end{array}$ & $80(72.1 \%)$ & $36(58.1)$ & 0.0602 \\
\hline
\end{tabular}

Cr: creatinine

ED LOS: emergency department length of stay

BUN: blood urea nitrogen 


\section{Discussion}

Several studies have demonstrated that elevated serum lactate is associated with higher morbidity and mortality in the setting of sepsis, shock, or trauma ${ }^{15,18,19}$. In our study population, there was no mortality; and after accounting for comorbidities, no statistically significant difference between patients with normal serum lactate and those with elevated serum lactate as illustrated in figure-1. This wasn't unexpected in that elevated lactic acid levels associated with seizure did not correlate with morbidity and mortality given the aforementioned pathophysiology of the transient nature of lactate production during seizure. This study reaffirms the understanding that lactic acidosis related to seizure self-resolves secondary to source control upon cessation of the event. The number of patients studied was significantly diminished after applying the exclusion criteria, which may have affected the power of the study and could explain why certain differences were not found between groups. Another limitation was that the length of the seizure and time of serum lactate collection in the ED could not be determined retrospectively. This may have had an effect on lab values as the half-life of lactate after grand mal seizure is approximately 1 hour ${ }^{11}$.

It has been shown that shorter waiting times in the ED are associated with decreased mortality and increased patient satisfaction ${ }^{20-22}$. Excessive patient wait times and disposition delays contribute to poor patient flow in the $\mathrm{ED}^{23}$. Our study found a significantly higher ED LOS by 60 minutes, in patients with normal serum lactate. This 
may have been because clinicians were searching for alternative diagnoses as normal lactate levels are generally not seen in the setting of the acute tissue hypoxia and hypoperfusion that seizures create. The current study found that a higher number of patients in the elevated serum lactate group received IV fluids, which was expected. These results outline possible areas of improvement with regard to mortality, patient satisfaction, and cost of care.

\section{Limitations}

The obstacles we encountered during the research are sample size, the patients that we reviewed their records might not be a true representation of the entire state or country health wise as not all the ED in the state of West Virginia participated in the research. Furthermore, several other pre-existing health problems in out participants may play the role of confounding in evaluating the levels of lactate during acute seizure.

\section{Conclusion}

Although there were no significant differences found with regard to morbidity and mortality between patients with normal or elevated serum lactate, we take this as further evidence to support the understanding that lactic acidosis secondary to seizure is a selflimited phenomenon, and that serum lactate level can be very useful in categorizing generalized tonic-clonic seizure from syncope and other forms of psychogenic nonepileptic seizures. If a patient presents to the ED with a seizure of unknown origin associated with increased lactate level, there should be a high suspicion for a generalized tonic-clonic seizure. Patients with normal serum lactate and with long LOS there is rapid normalization of serum lactate after a generalized seizure and so its value as a sole diagnostic tool for is limited. More so, serum lactate has time-dependent 
medRxiv preprint doi: https://doi.org/10.1101/2022.02.04.22270161; this version posted February 6, 2022. The copyright holder for this preprint (which was not certified by peer review) is the author/funder, who has granted medRxiv a license to display the preprint in perpetuity.

It is made available under a CC-BY-NC-ND 4.0 International license .

sensitivity and specificity as a diagnostic tool, its use could be compared with creatinine kinase and prolactin in a future prospective study to garner useful information that could be implemented for process improvement and cost containment strategies in the ED, and as a baseline for future projects

\section{References}

1. Epilepsy Foundation what is a seizure? [internet] Bowie, MD: Epilepsy Foundation, end epilepsy together; 2014 [cited 2021 Jun 04]. Available from: 2021:

https://www.epilepsy.com/learn/about-epilepsy-basics/what-seizure

2. Pallin DJ, Goldstein JN, Moussally JS, Pelletier AJ, Green AR, Camargo CA. seizure visits in US emergency departments: epidemiology and potential disparities in care. Int J Emerg Med 2008 Jun; 1(2):97-105

3. Begley CE, Durgin TL. The direct cost of epilepsy in the United States: A systematic review of estimates. Epilepsia 2015; 56: 1376-1387

4. Gale SC, Kocik JF, Creath R, Crystal JS, Dombrovskiy VY. A comparison of initial lactate and initial base deficit as predictors of mortality after severe blunt trauma. Journal of Surgical Research. 2016; 446:55.

5. Lee SM, Kim SE, Kim EB, Jeong HJ, Son YK, An WK. Lactate Clearance and Vasopressor seem to be Predictors for Mortality in severe sepsis patients with Lactic Acidosis Supplementing Sodium Bicarbonate: A Retrospective Analysis. PLoS ONE. 2015; 10:0145181-10.

6. Matz O, Heckelmann J, Zechbauer S, Litmathe J, Brokmann JC, Wilmes K, et al. Early Postictal serum lactate concentrations are superior to serum creatinine kinase concentrations in distinguishing generalized tonic-clonic seizures from syncopes. Intern Emergency Med. 2018; 13:749-755.

7. Nass RD, Sassen R, Elger CE, Surges R. The role of postictal laboratory blood analysis in the diagnosis and prognosis of seizures. Seizure. 2017; 47:51-65. 
8. Matz O, Zdebik C, Zechbauer S, Bundgens L, Litmathe J, Willmes K, et al. Seizure. 2016; 40:71-5.

9. Orringer CE, Eustace JC, Wunsch CD, Gardner LB. Natural history of Lactic acidosis after grand-mal seizures. A model for the study of an anion-gap acidosis not associated with hyperkalemia. N Engl J Med. 1977; 297:796-9.

10. Lipka K, Bülow H-H. Lactic acidosis following convulsions. Anesthesiology Scand. $2003 ; 47: 616-8$.

11. Vincent JL, Silva AQ e, Couto L, Taccone FS. The Value of blood lactate kinetics in critically ill patients: a systematic review. Crit Care. 2016; 1:257.

12. Centers for Disease Control and Prevention. U.S. Department of Health and Human Services. Epilepsy Data and Statistics [internet]. 2018 [cited 2021 Jun 04]. Available from: https://www.cdc.gov/epilepsy/data/index.html.

13. Kılıc TY, Yesilaras M, Atilla OD, Sever M, Aksay E. Can Venous blood gas analysis be used for predicting seizure recurrence in emergency department? World $\mathrm{J}$ Emergency Med. 2014; 5:187-91.

14. Dogan EA, Unal A, Erdogan C, Unal A. Clinical Utility of serum lactate levels for differential diagnosis of generalized tonic-clonic seizures from psychogenic nonepileptic seizures and syncope. Epilepsy Behav. 2017; 75:13-7.

15. Andersen LW, Mackenhauer J, Roberts JC, Berg KM, Cocchi MN, Donnino MW. Etiology and therapeutic approach to elevated lactate. Mayo Clin Proc. 2013; 88:1127-1140.

16. Gustafson ML, Hollosi S, Chumbe JT, Damayanti S, Modak A, Bethea A. The effect of ethanol on lacata and base deficit as predictors of morbidity and mortality in trauma. Am J Emerg Med. 2015; 33:607-613

17. Reddy AJ, Lam SW, Bauer SR, Guzman JA. Lactic acidosis: Clinical implications and management strategies. Cleveland Clinic Journal of Medicine. 2015; 82:615-

24. 
medRxiv preprint doi: https://doi.org/10.1101/2022.02.04.22270161; this version posted February 6, 2022. The copyright holder for this preprint (which was not certified by peer review) is the author/funder, who has granted medRxiv a license to display the preprint in perpetuity. It is made available under a CC-BY-NC-ND 4.0 International license.

18. Suetrong B, Walley KR. Lactic Acidosis in sepsis: It's not all anaerobic: Implications for Diagnosis and management. Chest. 2016, 149:252-61.

19. Aslar AK, Kuzu MA, Elhan AH, Tanik A, Hengirmen S. Admission lactate level and the APACHE II score are the most useful predictors of prognosis following torso trauma. Injury 2004; 35:746-752.

20. Geelhoed GC, de Klerk NH. Emergency department overcrowding, mortality and the 4-hour rule in Western Australia. Med J Aust. 2012; 6:122-6.

21. Guttmann A, Schull MJ, Vermeulen MJ, Stukel TA. Association between waiting times and short term mortality and hospital admission after departure from emergency department: population based cohort study from Ontario, Canada. BMJ. $2011 ; 342$ d 2983.

22. Taylor C, Benger JR. Patient Satisfaction in emergency medicine. Emergency Med J. 2004; 21:528-32.

23. Jarvis PRE. Improving emergency department patient flow. Clinical Experience Emergency Med. 2016; 30: 63-68. 
medRxiv preprint doi: https://doi.org/10.1101/2022.02.04.22270161; this version posted February 6, 2022. The copyright holder for this preprint (which was not certified by peer review) is the author/funder, who has granted medRxiv a license to display the preprint in perpetuity. It is made available under a CC-BY-NC-ND 4.0 International license .

Graph-1: Comorbidities in LA groups. 1-HTN; 2-DM; 3-CHF; 4-COPD; 5-Active Malignancy; 6CAD; 7-DVT; 8-Obesity; 9-Seizure Disorder; 10-Drug Addiction; 11-Alcoholism; 12-Other.

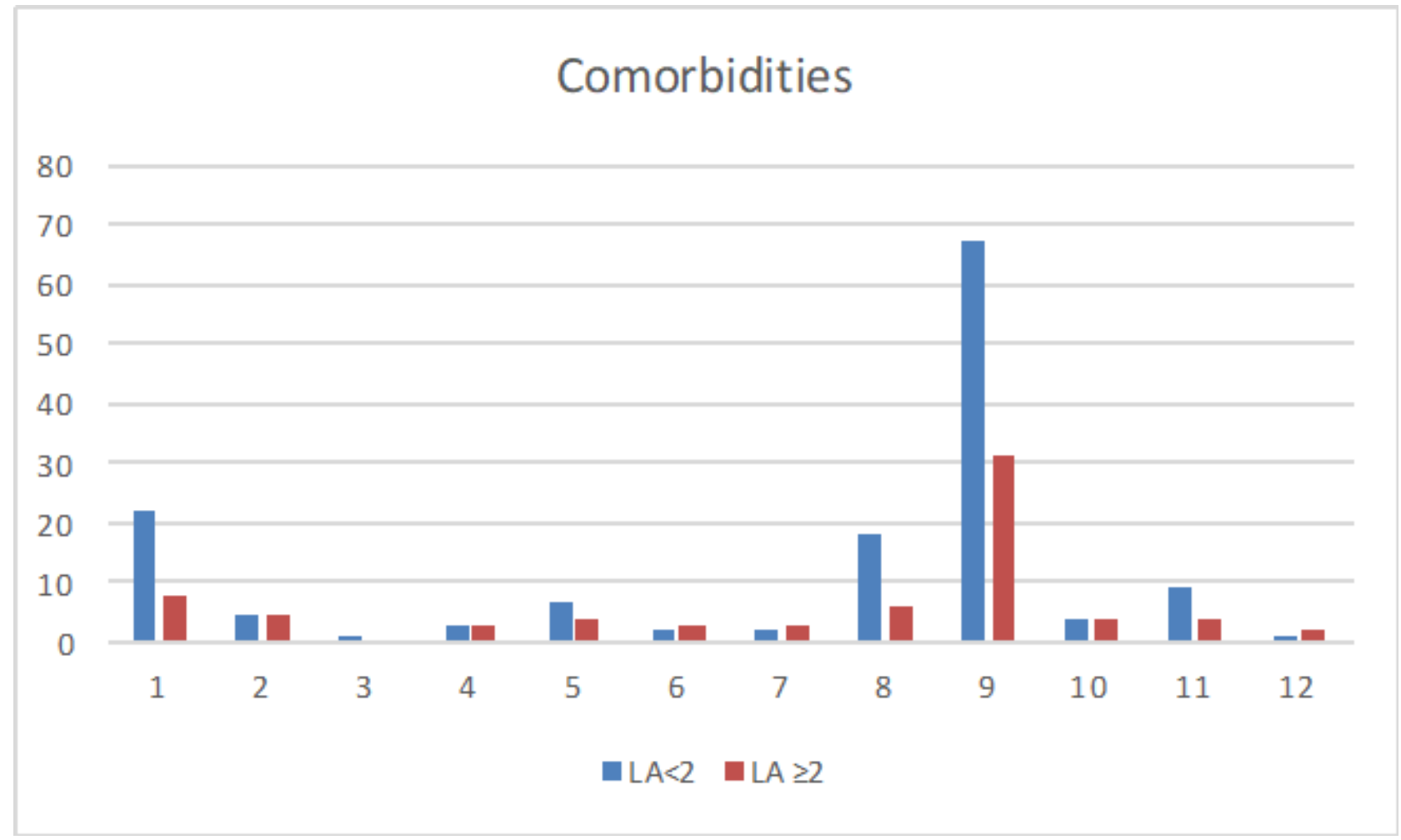

HTN: Hypertension

DM: Diabetes Mellitus

CHF: Congestive Heart Failure

COPD: Chronic Obstructive Pulmonary Disorder

CAD: Coronary Artery Disease

LA: lactic acid level in $\mathrm{mmol} / \mathrm{L}$ 
medRxiv preprint doi: https://doi.org/10.1101/2022.02.04.22270161; this version posted February 6, 2022. The copyright holder for this preprint (which was not certified by peer review) is the author/funder, who has granted medRxiv a license to display the preprint in perpetuity.

It is made available under a CC-BY-NC-ND 4.0 International license. 